\title{
Mesocyclops dissimilis n. sp. from Lake Biwa, Japan (Copepoda, Cyclopoida)
}

\author{
Danielle Defaye $^{1}$ \& Keiichi Kawabata ${ }^{2}$ \\ ${ }^{1}$ Muséum National d'Histoire Naturelle, Laboratoire de Zoologie-Arthropodes, 61, ne de Buffon, F-75005 \\ Paris, France; ${ }^{2}$ Department of Biology, Faculty of Education, Kanazawa University, Marunouchi, \\ Kanazawa 920, Japan
}

Received 7 April 1992; in revised form 25 June 1992; accepted 20 August 1992

Key words: Copepoda, cyclopoida, fresh-water, Mesocyclops dissimilis n. sp., Lake Biwa, Japan

\begin{abstract}
The status of the Mesocyclops from lake Biwa is reexamined and a new species, Mesocyclops dissimilis n. sp., distinct from $M$. thermocyclopoides Harada, 1931, is described.
\end{abstract}

\section{Introduction}

The genus Mesocyclops (Copepoda, Cyclopidae) is common in the freshwaters of the world. It occurs everywhere, but is especially common in the tropics. More than 60 different species have been described (Dussart \& Defaye, 1985 and new data). Until the detailed studies by Kiefer (1981), Dussart $(1982,1984)$ and Van de Velde (1984), Mesocyclops leuckarti (Claus, 1857) described from Germany, was considered to be cosmopolitan. In Japan, the $M$. 'leuckarti' from Lake Biwa was re-allocated to $M$. thermocyclopoides Harada, 1931 (Kawabata, 1989). A new study of samples collected by $\mathrm{Mr} \mathrm{T}$. Ueda, Otsu Hydrobiological Station, Kyoto University, and one of us (K.W.) now leads us to establish a new species of Mesocyclops, Mesocyclops dissimilis n. sp. from Lake Biwa.

\section{Material examined}

Holotype: female, deposited in the Muséum national d'Histoire Naturelle, Paris (France) as MNHN Paris-Cp941, dissected (4 slides) in glyc- erol, mounted with Eukit (O. Kindler GmbH \& Co, Freiburg, FRA), from the south basin of Lake Biwa, near OHBS, 11-07-1988, T. Ueda coll.

Allotype: male, deposited in the Muséum national d'Histoire Naturelle, Paris (France) as MNHN Paris-Cp942, dissected (3 slides) in glycerol, mounted with Eukit, from the south basin of Lake Biwa, near OHBS, 11-07-1988, T. Ueda coll.

Paratypes: 1 female, dissected as Holotype and Paratype, of same origin (MNHN Paris-Cp943), 5 undissected specimens ethanol-preserved (females), same origin (MNHN Paris-Cp 944).

Other material examined: about 20 specimens conserved in one of the authors' collection (D.D.) of same origin as the types. Samples from older collections in the north basin of Lake Biwa (Kawabata, 1989) have been examined too: 7 specimens from 9-5-1985, 12 from 12-7-1985; 8 from 2-9-1986.

\section{Description of female (Figs 1-15)}

Length excluding furcal setae: $1200 \mu \mathrm{m}$ (range: $1080-1200 \mu \mathrm{m}, m=1120, n=8$ ).

Antennule (Fig. 14-15) of 17 segments, reach- 


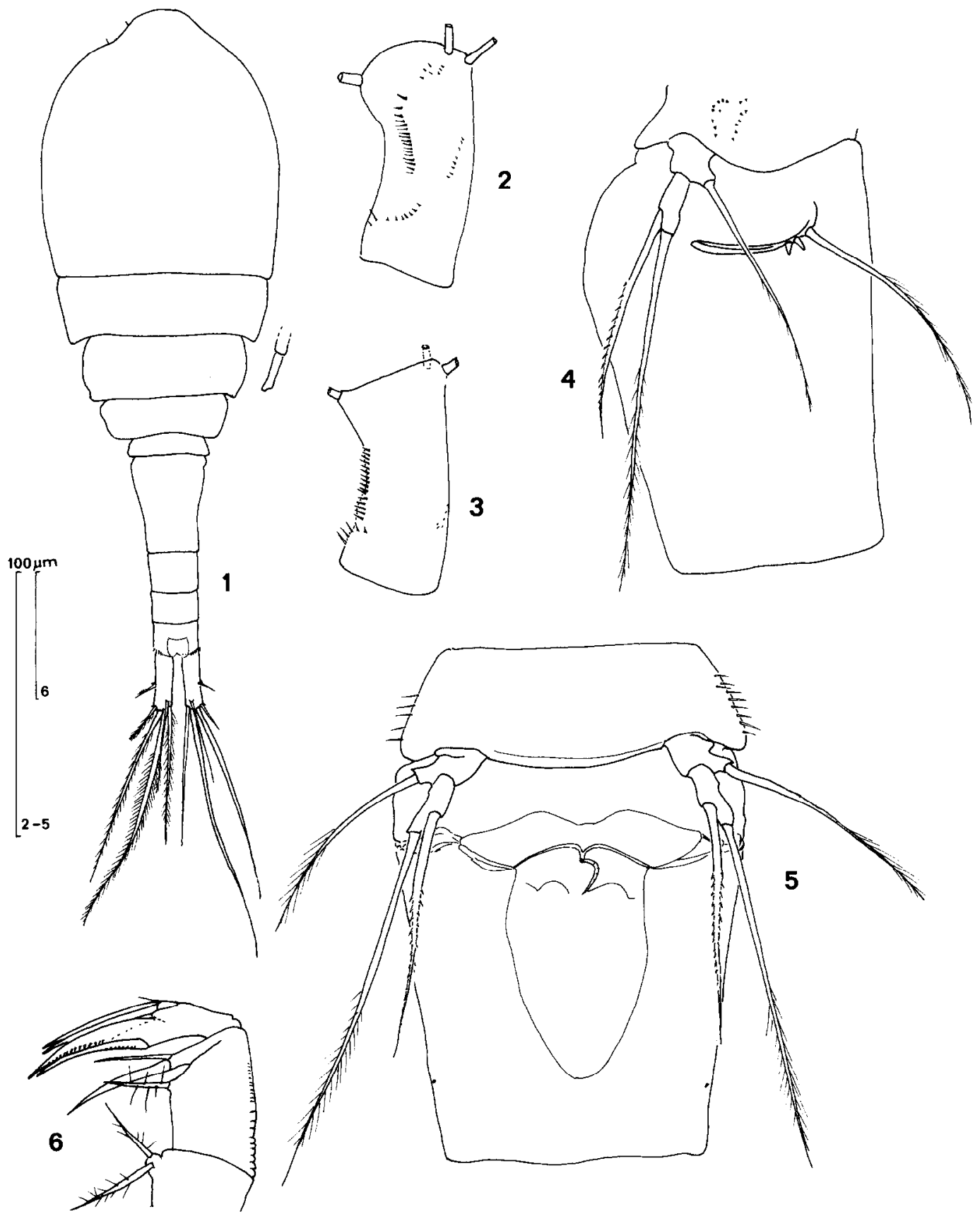

Figs 1-6. Mesocyclops dissimilis n. sp. Female. 1. Habitus; 2. Basipodite A2, caudal side; 3. Basipodite A2, frontal side; 4. P5, P6; 5. Genital segment; 6. Maxilla (part).

ing distal margin of third thoracic somite. Armature as in Fig. 14.

Last two segments identical in length and longer than antepenultimate one. Hyaline membrane on last segment with 2 small notches.

Antenna segmented as in all Mesocyclops. 

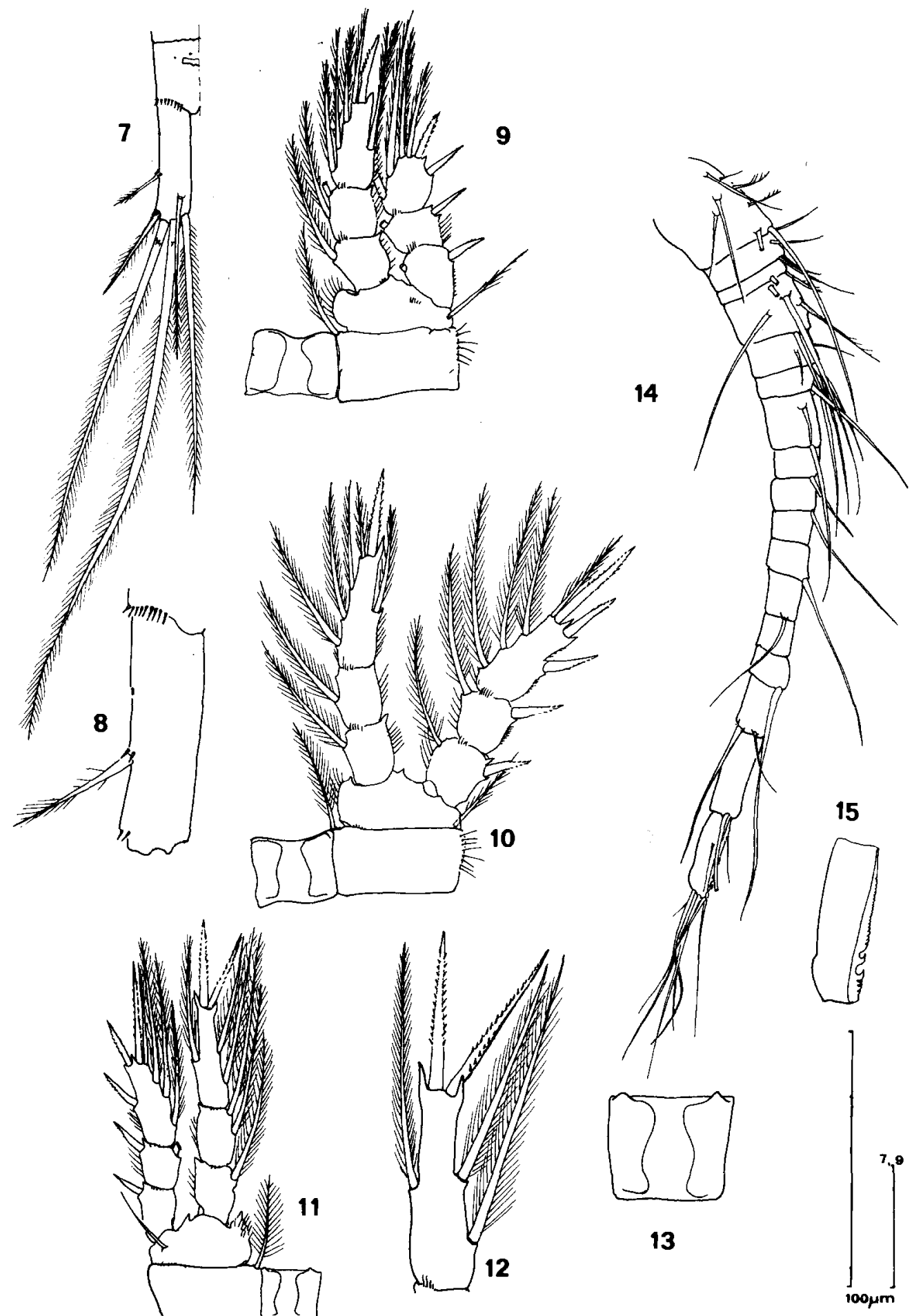

14

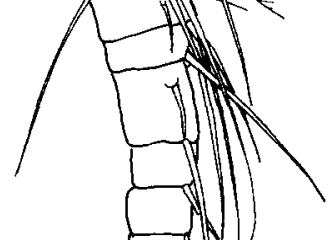

Figs 7-15. Mesocyclops dissimilis n. sp. Female. 7. Furcal ramus; 8. Furcal ramus, detail; 9. P1; 10. P2; 11. P4; 12. Enp3P4; 13. Precoxal plate P4; 14. Antennule; 15. Last segment of antennule. 


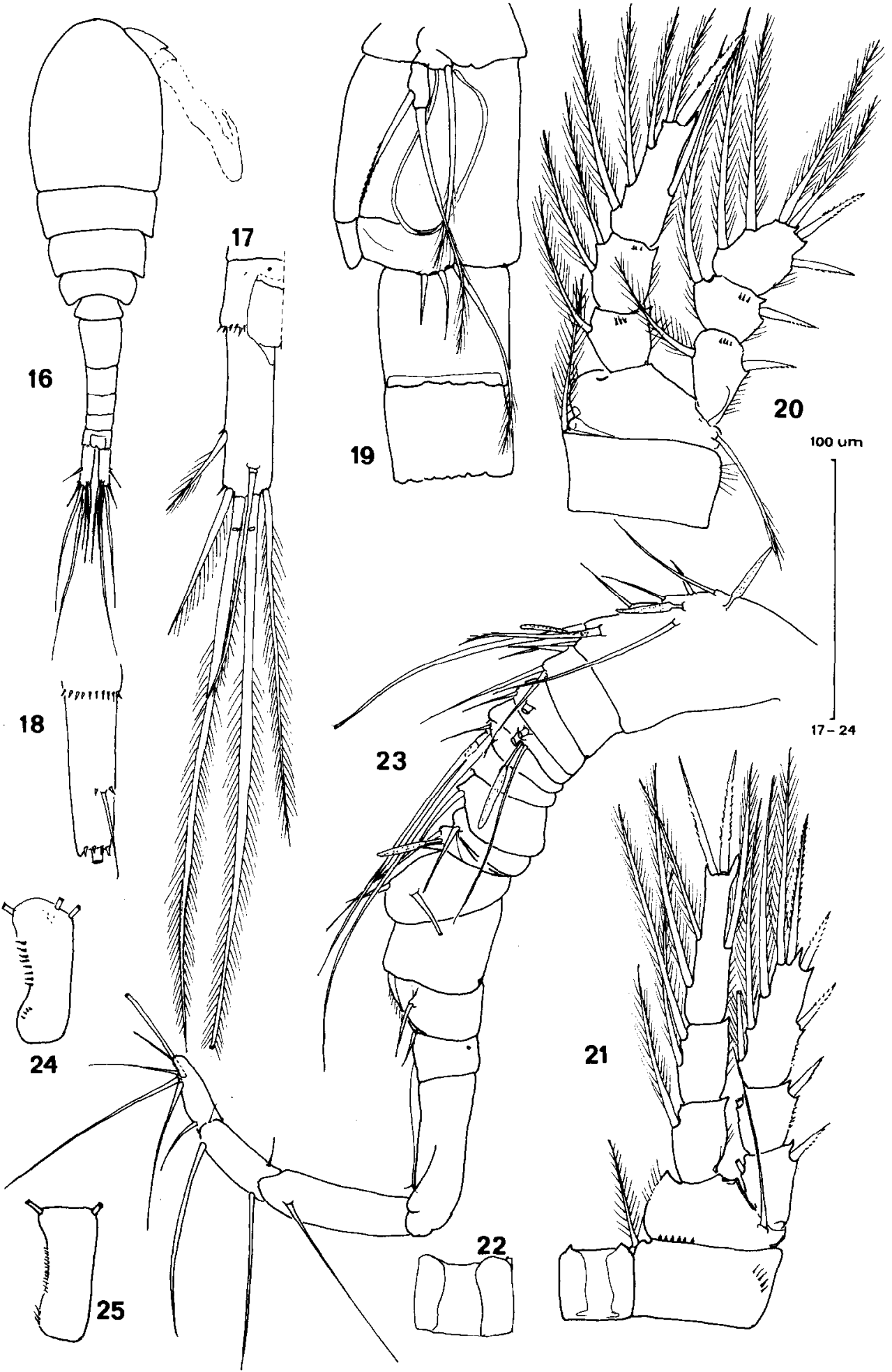

Figs 16-25. Mesocyclops dissimilis n. sp. Male. 16. Habitus; 17. Furcal ramus; 18. Furcal ramus, detail (profile); 19. P5, P6; 20. P1; 21. P4; 22. Precoxal plate P2; 23. Antennule; 24. Basipodite A2, caudal side; 25. Basipodite A2, frontal side. 
Structure of basipodite as in Figs 2-3. Following Van de Velde's (1984) terminology, longitudinal row of spines on frontal side composed of 16 spinules; longitudinal row on caudal side of 16 spinules, with one a little longer, separated from the others; the row proximal to this row has 9 spines. A small group of 7 minute spinules situated distally on basipodite. A line of 8 minutes spinules placed obliquely near internal edge of segment. The variability observed is limited to two spines more or less in the different rows of spinules.

Basis of maxillulary palp without a group of spinules. Maxilla with external edge ornamented as in Fig. 6.

P1 to P4: Spine and setae formulae typical for genus (spine formula: 2.3.3.3.); precoxal plates (Fig 9, 10, 13), without any spine or seta. P1 to P3 (Fig. 9-10) (P2 of same formula as P3) without proeminence observed at distal edge of precoxal lamella. Only two small triangular proeminences just reaching over margin of precoxal lamella of P4.

P1 (Fig. 9) without frontal spine at inner distal margin of basipodite.

P4 (Fig. 11-13): Enp3 3.15 times as long as wide ( 2.92 to $3.50, m=3.22, n=7)$. Inner apical spine slightly longer than outer (1.06 times, from 0.98 to $1.20, m=1.08, n=8)$ ). These two spines shorter than segment.

P5 (Fig. 4-5): Apical seta much longer than spinous seta inserted on same segment and passing over distal margin of genital segment of Abd 2.

P6 (Fig. 4) composed of 2 internal, small spines and a long dorsal seta, almost reaching distal margin of genital somite.

Last thoracic somite with two rows of setae on each lateral side.

Genital somite longer than larger. Receptaculum seminis: see Fig. 5. Genital field with two short lateral arms slightly curved at their ends. Posterior margin of proximal part slightly Vshaped from copulatory pore. Pore-canal curved to the right, as a long comma.

Ovigerous sacs rounded, in dorsal position, with about 12 medium-sized eggs.
Furcal rami (Fig. 7-8) not pilose on inner margin, 3.57 times ( $m=3.86, n=7)$ as long as wide. Lateral and external terminal setae with spines at their base. Dorsal seta (Ds) shorter than internal seta (Is) (Ds/Is $=0.55$ in holotype, variable between 0.42 to $0.55, m=0.52, n=8$ ), longer than external seta (Es), this last one 3 times (2.72 to $2.96, m=2.87, n=8$ ) shorter than internal seta.

\section{Description of male (Fig. 16-24)}

Length excluding furcal setae: $742 \mu \mathrm{m}$ (range: 640-780, $m=724, n=6$ ).

Antennule (Fig. 23) with 3 aesthetascs on first segment, 1 on 4 th and 1 on 9th segment. Same characteristics for buccal appendages as in female. About same general pattern of spines on basipodite of antennae (Fig. 23-34) as in female, but number of spines reduced. Furca with rami 3.15 longer than wide $(3.15-3.75, m=3.31, n=5)$, with same denticles at base of lateral and external setae. Dorsal seta (Ds) shorter than internal (Is), (Ds/Is $=0.64,0.64$ to $0.67, m=0.65, n=5)$, relatively longer than in female. Dorsal seta longer than external seta (Es), this latter 2.5 times (2.27 to $2.73, m=2.50, n=5$ ) shorter than internal seta. No setae on lateral edges of last thoracic segment.

$\mathbf{P} 1$ to $\mathbf{P} 4$ with same structure as in female.

Precoxal plates of $\mathbf{P} 1-\mathbf{P} 4$ similar to female. $\mathbf{P} 1$ (Fig. 20) without any spine at inner distal margin of basipodite. Enp3 P4 (Fig 21) 3.27 times longer than wide $(m=3.31, n=5)$, with internal terminal spine longer than external one (1.14 times, $m=1.07, n=5)$.

P5 (Fig. 19) very long, as in female; seta on second segment almost reaching distal margin of Abd 2 and seta of first segment as long as Abd1. P6 composed of 3 relatively long setae; more dorsal one almost as long as $\Lambda \mathrm{bd} 3$.

If we consider the short description and the few criteria of Harada (1931) this species corresponds to $M$. thermocyclopoides, even if the present species is larger. 


\section{Discussion}

Our specimens from Lake Biwa were compared with $M$. thermocyclopoides Harada, 1931, from lake Candidius (Formosa) (Ueno leg., Kiefer's slide collection deposited in Landessammlungen für Naturkunde Karsruhe). Further, after reference to Kiefer (1981)'s revision of Mesocyclops, it is clear that the species described here has affinities with true $M$. thermocyclopoides Harada, but differs from it in the following respects: the spine pattern on the basipodite of the antennae; the structure of the receptaculum seminis (shape of arms, posterior margin, position of the copulatory pore). Moreover, there is no spine at the base of the lateral and external furcal setae.

The species studied here also presents affinities with Mesocyclops notius Kiefer, 1981 in the structure of the precoxal plate of P1 to P4, the absence of a spine at the inner margin of the basipodite of $\mathrm{P} 1$, the setae on the two sides of Th5 (characters common with $M$. thermocyclopoides from lake Candidius), the spines present at the base of the lateral and external furcal setae, the shape of the posterior margin of the proximal part of the receptaculum seminis. It differs from this Australian species by other characters: the general shape of the receptaculum seminis, the spine pattern of the basipodite of the antenna, the dorsal furcal seta (longer than in $M$. notius and than in $M$. thermocyclopoides - the dorsal seta is 1.6 (mean) longer than the external setae in $M$. dissimilis and 1.3 (mean) in $M$. notius -), the P5 with very long terminal seta.

We conclude that our Mesocyclops species is different from $M$. thermocyclopoides Harada, 1931 by enough characters to consider it a good species, which we call dissimilis $\mathbf{n}$. $\mathbf{s p}$. in relation to its difference to $M$. thermocyclopoides.

Mesocyclops thermocyclopoides occurs in Australia (N. S. Wales, Victoria) and in South-East Asia, Formosa, Thailand and Burma, but also in Kalimantan, Nepal, Sulawesi (Dussart \& Fernando, 1986). Mesocyclops notius is, until now, restricted to Australia. The new species shows affinities with these two last species and could belong to the same 'group', when considering such characters as absence of a spine at the inner margin of basipodite of $\mathrm{P} 1$, structure of the precoxal lamellae of $\mathrm{Pl}$ to $\mathrm{P} 4$, armature of the apical spines of Enp3 P4, presence of setae on the lateral edge of Th5, and presence of a very long dorsal furcal seta.

Mesocyclops 'leuckarti' from the north as well as the south basins of Lake Biwa is in fact Mesocyclops dissimilis $\mathrm{n} . \mathrm{sp}$. The samples of Mesocyclops thermocyclopoides recorded in Kawabata (1989) have been examined again and are also Mesocyclops dissimilis $\mathrm{n}$. sp. However, we do not exclude the possibility of the presence of other Mesocyclops in lake Biwa.

\section{Acknowledgements}

We thank M. T. Ueda for collection of samples, Dr Dussart for his advice and Dr Mittman from Landesammlungen für Naturkunde Karsruhe (Germany) for the loan of Kiefer collection's Mesocyclops types.

\section{References}

Dussart, B. H., 1982. Faune de Madagascar. Crustacés Copépodes des eaux intérieures. ORSTOM/Paris $146 \mathrm{pp}$.

Dussart, B. H., 1984. Sur quelques Copépodes d'Amérique du Sud. Archiv f. Hydrobiol. 103: 201-215.

Dussart, B. H. \& C. H. Fernando, 1986. The Mesocyclops species problem to-day. Syllogeus $\mathrm{N}^{\circ} 58$, Nat. Mus. Canada: $288-293$.

Dussart, B. \& D. Defaye, 1985. Répertoire mondial des Crustacés Copépodes Cyclopoïdes. Editions CNRS, Bordeaux/ Paris $236 \mathrm{pp}$.

Harada, I., 1931. Studien über die Süsswasserfauna Formosas. IV. Süsswasser-Cyclopiden aus Formosa. Annot. Zool. Japon 13: 149-168.

Kawabata, K., 1989. Seasonal changes in abundance and vertical distribution of Mesocyclops thermocyclopoides, $C y$ clops vicinus and Daphnia longispina in Lake Biwa. Jpn J. Limnol. 50: 9-13.

Kiefer, 1981. Beitrag zur Kenntnis von Morphologie, Taxonomie und geographischer Verbreitung von Mesocyclops leuckarti auctorum. Arch. Hydrobiol., Suppl. 62: 148-190.

Van de Velde, I., 1984. Revision of the African species of the genus Mesocyclops Sars, 1914 (Copepoda: Cyclopidae). Hydrobiologia, 109: 3-66. 